WellBeing International

WBI Studies Repository

1998

\title{
Contested Moralities: Animals And Moral Value in the Dear/ Symanski Debate
}

\author{
William S. Lynn \\ Green Mountain College
}

Follow this and additional works at: https://www.wellbeingintlstudiesrepository.org/acwp_habr

Part of the Animal Studies Commons, Other Anthropology Commons, and the Religious Thought, Theology and Philosophy of Religion Commons

\section{Recommended Citation}

Lynn, W. S. (1998). Contested moralities: Animals and moral value in the Dear/Symanski debate. Ethics, Place \& Environment, 1(2), 223-242.

This material is brought to you for free and open access by WellBeing International. It has been accepted for inclusion by an authorized administrator of the WBI Studies Repository. For more information, please contact wbisr-info@wellbeingintl.org.

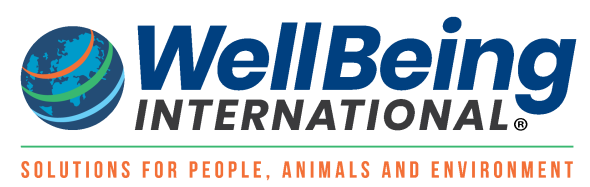


Lynn, William S. 1998. Contested Moralities. Ethics, Place and Environment 1:2, 223-242.

\title{
Contested Moralities: Animals And Moral Value in the Dear/Symanski Debate
}

\author{
William S. Lynn
}

ABSTRACT Geography is experiencing a 'moral turn' in its research interests and practices. There is also a flourishing interest in animal geographies that intersects this turn, and is concurrent with wider scholarly efforts to reincorporate animals and nature into our ethical and social theories. This article intervenes in a dispute between Michael Dear and Richard Symanski. The dispute is over the culling of wild horses in Australia, and I intervene to explore how geography deepens our moral understanding of the animal/ human dialectic. I begin by situating the inquiry into ethics and animals in geography. Next, I provide a synopsis of Dear and Symanski's comments on 'animal rights', followed in turn by discussions of moral value and value paradigms. I then introduce a value paradigm termed geocentrism as a geographical account of our moral relations to animals. Finally, I discuss the wider significance of this debate for geographical ethics, moral philosophy and social theory.

The world, we are told, was made especially for man — a presumption not supported by all the facts. A numerous class of men are painfully astonished whenever they find anything, living or dead, in all God's universe, which they cannot eat or render in some way what they call useful to themselves. They have precise dogmatic insight of the intentions of the Creator.... Now, it never seems to occur to these far-seeking teachers that Nature's object in making animals and plants might possibly be first of all the happiness of each one of them, not the creation of all for the happiness of one. Why should man value himself as more than a small part of the one great unit of creation?

John Muir (1916) Anthropocentrism and predation, in $A$ Thousand-Mile $W$ alk to the Gulf.

In 1994 the Annals of the $A A G$ featured a heated exchange between Michael Dear and Richard Symanski on the topic of postmodernism. Using a dispute over the culling of wild horses in Australia, Symanski sought to illustrate the baneful effect of postmodern relativism on truth, and this illustration became a flash-point in the subsequent exchange with Dear (Dear 1994; Symanski 1994, 1994). In the minds of many of my colleagues, the exchange produced more heat than light, and they found the discussion perplexing and pointless. While some were simply unfamiliar with the theoretical terrain of postmodernism, others did not see what postmodern contentions about truth had to do with the ecology of Australian wild horses. In effect they were asking: "What in the world could ecology and postmodernism possibly have to do with one another?" In point of fact, a

William S. Lynn, Geography and Environmental Studies, Green Mountain College, One College Circle, Poultney, VT, 05764-1199, USA 
postmodern turn in environmental studies is quite evident, both within and outside geography (Cheney 1989; Gare 1995; Haraway 1991; Soule and Lease 1995). Part of this turn is motivated by a concern for discourse and positionality, that is, with how our conceptual maps about science, nature and society, as well as the power relations between differing groups, realize scientific and popular understandings concerning the natural world. ${ }^{\text {ii }}$

What is often missing from the postmodern turn is a substantive engagement with ethics, especially animal and environmental ethics. This is not a special fault of postmodernism, but a trait shared with most materialist and scientistic research in geography and other social sciences. This shared lacuna frequently renders a moral concern for non-humans fallacious and inconsequential to many postmodernist, materialist, and scientistic minds. iii In geography this has taken the form of a widespread and credulous assertion that nature is socially constructed, along with the erroneous notion that ethical discourse must be relativist or imperialist (Demeritt 1994, 1994; FitzSimmons 1989; Smith 1984; Willems-Braun 1997). So I am pleasantly surprised by the exchange between Dear and Symanski, a postmodern and 'scientist' respectively. What intrigues me is how their debate reflects presuppositions about humanity's relationship to the animal world. While interwoven in another argument, their debate about horses reveals explicit moral sensibilities towards animals and the rest of nature. Their exchange also calls attention to a research agenda increasingly important to other geographers, research I describe as ethically engaged animal geography.

I will not be analyzing the larger points addressed by Symanski (postmodernism and the politics of truth) or Dear (postmodernism's critique of privileged epistemologies). These form the textual backdrop to the exchange of moral views. My intent is to critically evaluate Dear and Symanski's assumptions about the moral value of animals. I do this to help all of us reflect on our own ethical assumptions about the non-human beings of the natural world. A brief synopsis of their debate, however, is as follows. Symanski begins with an article on Brumbies, the wild horses of Australia's outback. ${ }^{\text {iv }}$ He notes the damage these exotics cause native species and biomes, dismisses the concerns of animal rights advocates, decries the politics that undercuts feral horse reduction programmes, and takes a parting swipe at postmodernism for reputedly legitimizing disingenuous claims about relativized truth (Symanski 1994). Dear responds with a paean to postmodernism, claiming it has liberated us from Enlightenment essentialisms and other privileged forms of knowing. He also states what he wishes Symanski would say about nature, objectivity, language, and politics. As part of this commentary, Dear allows for the moral legitimacy of animal rights, and positions postmodernism at the leading edge of environmental thought (Dear 1994). In his retort to Dear, Symanski accuses Dear's ancestors of environmental crimes, reiterates his dismissal of animal rights, condemns again the relativization of truth, and associates Dear with "reactionary" politics (Symanski 1994).

I begin by situating the inquiry into ethics and animals in geography. Next, I provide a synopsis of Dear and Symanski's comments on 'animal rights', followed in turn by discussions of moral value and value paradigms. I then introduce a value paradigm termed geocentrism as a more geographical account of our moral relations to animals. Geocentrism helps us avoid dualistic views of the animal/human dialectic, and create shared moral ground for environmental controversies requiring hard choices. Finally, I discuss the wider significance of this debate for geographical ethics, moral philosophy and social theory. Because this text is a hermeneutic reading of Dear and Symanski's presuppositions, I conclude with a caveat, requesting that they offer further clarification and corrections to my interpretation of their views. 


\section{Contested Moralities}

\section{Situating Ethics and Animals}

How shall we situate this debate within geography? Animal ethics is admittedly distant from the research of most geographers, so how did this topic get 'inside' our discipline? We can begin by reminding ourselves that geography is constitutive of ethics, generating conceptual and contextual insights that inform moral theory and method (Lynn 2000). As elements of context and attributes of theory, the ideas of space, place and nature have been presuppositions of moral discourse for most of history. Considered in this way, moral queries about the natural world (including animals) did not somehow infiltrate geography, but have been here all along. This should come as no surprise as there has always been a moral voice (for better or worse) in geographic inquiry. The genealogy of ethics in geography is not only ancient, but also laden with more or less transparent moral presuppositions and intentions. These 'moral geographies' are of many sorts-classical regionalizations of cultural and moral diversity, the rhetorics of colonization and imperialism, the teleological explanations of the natural world, the 'mores' of social Darwinism and environmental determinism, post-positivist concerns with relevance and values, the emphasis on justice in critical geographies, and the now increasingly explicit investigation of professional, applied, and to a lesser extent, theoretical ethics (see Herodotus 1996; Khaldun 1981; Blaut 1993; Glacken 1967; Livingstone 1992, chapters 5-7; Johnston 1997, chapters 7 \& 9).

Moreover, ethics has historically been a form of practical reasoning. Practical reasoning differs markedly from the analytic reasoning that dominates modern moral philosophy (e.g., utilitarianism, deontology, contractarianism). Modern moral philosophers seek a trans-geographical truth, which is to say, deductive axioms of conduct, derived without the benefit of geographic or historical contextualization, and equally applicable to all people, places and circumstances. This not the case, however, for the practical reasoning that is part of alternative traditions of moral philosophy (e.g., casuistry, hermeneutics). Practical reasoning seeks to articulate situationally sensitive principles to guide us in moral and political deliberation. In this view, ethics is not a timeless and placeless code of rules, but the use of moral concepts as rules-of-thumb that help us answer "how we ought to live" (Aristotle 1985; MacIntyre 1966; O'Neil 1996).

After several decades where moral concerns were eclipsed by putatively value-neutral regional and spatial paradigms, the discipline is experiencing a 'moral turn' in its research interests and practices (Lynn 2000, chapters 1-2; 1997). The burgeoning interest in animal geographies intersects this moral turn (e.g., Emel and Wolch 1995; Wolch and Emel 1995, 1998; Lynn 1995), is concurrent with a larger effort to reincorporate animals and nature into moral understanding and social theory (e.g., Benton 1993; Ingold 1988; Kellert 1996; Mack 1995; Noske 1997; Shepard 1996; Spiegel 1988), and highlights the controversy over our moral relationship with animals (e.g., Midgley 1984, 1995; Regan 1983; Singer 1975; Sorabji 1993; Taylor 1986). Dear and Symanski insert themselves, therefore, into an intricate nexus of inquiries regarding animals, ethics, and now, geography. Yet the Dear/Symanski debate is significant not for the bulk of its content, but for how it manifests value paradigms affecting the moral status of animals. Paradigms of moral value are foci for determining membership in moral/political communities. By making the latent manifest, Dear and Symanski open a conceptual space for the interrogation of our value paradigms relating to animals, a space I use as an invitation to extend our moral horizons. 
William S. Lynn

\section{Moral Rights and Wild Horses}

Let us begin with Dear. He defends the possibility of animal rights activists having a "considered ethical opinion" regarding horse reduction programmes. A "horse lover" himself, Dear is disappointed in Symanski's approach to environmental geography, especially as it relates to animals (Dear 1994: 296). In a section entitled "Horses Have Rights, Too", Dear characterizes Symanski's environmental ethic as "stubbornly anchored in an outmoded Judeo-Christian tradition that emphasizes Man's Dominion Over Nature", and wishes that Symanski would show "a greater sensitivity to our place in the animal's world" (Dear 1994: 297). Finally, Dear positions postmodernism "at the forefront of a reconceptualization of the relationship between people and the natural world. Among other things, this involves dismissal of the Man-Nature dualism and an ecology-based emphasis on the essential unity of the natural world.... In practical terms, such viewpoints place greater emphasis on conservation and restoration rather than the exploitation of nature" (Dear 1994: 297).

For his part, Symanski is hostile to animal rights activists, terming them "crackpots", "none of whom...know more than a pittance about ecology or the Outback or its native species or extinction rates or carrying capacities" (Symanski 1994: 301, 302). He asserts that his is the view of a true biocentrist, having taught several courses with "some form of biocentric philosophy" as a "centerpiece idea" (Symanski 1994: 301). Thus he claims that Dear "has little reason to be taking the high-moral ground with me, implying that like all good postmodernists, he embraces a biocentric point of view. Were it true, one would expect Dear to be as keen as I am to rid the Australian outback of calamitous introduced feral species—not just horses" (Symanski 1994: 301). Finally, Symanski suspects that "Dear and other horse lovers like him would readily agree with the way I have treated the off-the-wall opinions of these animal rights activists once they confronted these people in person, and once they learned a bit about ecology and the ravaged Outback and its disappearing native species" (Symanski 1994: 302).

With both authors staking claims to higher moral ground, it can be difficult to decide whether one or the other is right or wrong. And what if neither is right or wrong per se: Are there mediating or alternative positions to consider? How are we, then, to make sense of this exchange? I do so by conceiving it as a dispute over the moral value of animals, and by implication of nature itself. Geographers are accustomed to valuing animals and nature in terms of aesthetic, economic, recreational, and scientific values. But moral value-why is this relevant? To explore this question, we first need to clarify the meaning of 'value' in ethics.

\section{Moral Value}

Value derives from the Latin "valere" (to be strong, to be worthy), and connotes worth, goodness, or desirability (Runes 1982: 346). Value is one of this century's most complex words. Individuals refer to values by way of articulating (if imprecisely) those dimensions of personal and social experience which, in their opinion, are particularly important or worthy, e.g., 'my values', 'family values', the 'value of education', etc. Economists (ecological and otherwise) commonly speak of monetary or use value, phrasing in economic terms the utilities of human or natural 'resources' (e.g., Daly and Townsend 1993). In the social sciences we speak of social values in several ways-as objects of inquiry, as a category of social theory, and as a philosophical problem of distinguishing factual and evaluative statements (Outhwaite and Bottomore 1993, 694-696). Thus in both popular and academic discourse, value has wide-ranging connotations, many of which refer to moral 


\section{Contested Moralities}

sensibilities rooted in personal preferences or social norms. There are trenchant critiques of uncritically conflating preferences and norms by calling them 'values', then confusing values and ethics by eliding their distinct meanings (e.g. Winner 1986: chap 9). I will not be using value so loosely in this chapter. At its most basic level, if values are those things (objects, beliefs, behaviours, etc.) we think important, then moral values are things that are important for moral reasons. More specifically, I highlight three specific meanings of moral value, which are important elements in any discussion of animal and environmental ethics. Unfortunately, these meanings are implicit to many moral arguments and, to make matters worse, are frequently confused with one another. Identifying and clarifying these terms will help us avoid confusion as we progress through this interpretation.

First, moral value is a distinctive and intrinsic property of a being or thing, a property that is valuable and/or necessary for cogent ethical reasoning. The characteristic of sapience (self-awareness) is a good example. Sapience is a defining species trait of human beings (and some other animals). It is consequently a necessary consideration when thinking about our moral relations to people (and other sapient beings). How could we even think about our ethical responsibilities to our children, for instance, if we did not take into account their eager awareness and engagement with their world, their need for love, friendship, challenge, discipline, and learning, all of which are human capacities made possibly by sapience? Thus sapience is a moral value because it is conceptually necessary for the moral understanding of humans and other animals. Sapience is not the only property that qualifies as a moral value. Other properties have been proposed, including sensory awareness and the ability to feel physical pain (sentience), caring social relationships with other animals (human and non-human), a biophilic response to all life, and the integrity of ecological relationships (see Regan 1983; Singer 1993; Gaard 1993; Wilson 1984; Rolston 1988). The key here is to spurn totalizing categories of moral value, and instead identify those properties that are necessary or germane to moral understanding, an act of interpretation dependent on context and good judgment (see Naess 1989; Midgley 1984).

To further specify moral value as a property, consider how we use sapience as a moral value whenever we discuss population. Whereas we often discuss human population issues with reference to the social and cultural affairs that affect individual choice and empowerment, we routinely discuss wildlife population issues in terms of the production and harvesting of animal 'resources'. The difference in these two representations of population management is a moral one. Having the moral value of sapience, humans are regarded as persons, and therefore accorded some degree of respect for their desires and choices. Without the moral value of sapience, non-human animals are not regarded as persons, and are managed like any other agricultural commodity (compare Bailey 1984; Mazur 1994). ${ }^{\text {vi }}$

Second, there is an important distinction between different kinds of morally relevant values, specifically intrinsic and instrumental value. When we say, for example, that animals are ends in themselves, and that humans have serious ethical duties to non-human creatures, we are claiming that animals have intrinsic value. Alternatively, when we say that animals are only means to human ends, and that we have no moral duties to these creatures, we are claiming that animals have instrumental value. In the above example of population management, sapience is frequently said to give humans intrinsic moral value. Reputedly lacking sapience, animals are assigned only instrumental value.

Third, concepts of moral value lie at the core of ethics, and nowhere is this truer than in animal and environmental ethics. The reason is simple. Moral value is the usual (albeit often implicit) criterion by which we determine who (or what) has moral standing, that is, who (or what) is deserving of moral 
consideration, is within our moral community, and to whom we have moral responsibilities. Moral value also serves as the criterion by which we assess moral significance, that is, the relative importance of competing ethical claims or concerns (Fox 1990: 149-196; Simmons 1993: 124-125). We should ask ourselves, therefore: "What is the moral value of animals? Do they have standing in our moral community, and if so, what is the significance of their needs?” If we return to our previous example, we can easily see how moral standing and significance illuminates conventional attitudes to population management. Because of our sapience, human beings have moral standing and are members of a community to whom we have moral responsibilities. Population policy should be developed with this in mind, as is the case with population programmes that focus on the health, security and empowerment of women. Because animals supposedly lack sapience, they stand outside the moral community and their well-being is of no direct significance to us. According to conventional wisdom, managing the population of animals is therefore not an ethical issue, but an economic and ecological matter of efficiency and biodiversity. Yet even if we were to acknowledge sapience in both humans and some animals, we still make judgments about the comparative significance of their moral concerns. When we choose to build sport stadiums instead of lower income housing, or golf courses instead of protecting or restoring wildlife habitat, we are prioritizing well-off humans at the expense of the poor and animals. Obviously these ethical judgments can be for better or worse, and are as frequently implicit as they are explicit, but they are judgments about the significance of morally relevant claims nonetheless.

Consider another case, that of the endangered red wolf (Canis rufus), once endemic in southeastern North America, which was nearly exterminated through trapping and habitat destruction and is now the subject of a US Fish and Wildlife Service reintroduction programme at Alligator National Wildlife Refuge. Does the red wolf have intrinsic value? Is it a part of our moral community? If so, what responsibilities have we to red wolves? Should we restore their habitat and aid in their repopulation of the southeast region? What are the intentions of this restoration? Do we restore habitat and return wolves to the wild for the benefit of humans, or out of respect for wolves themselves? And whatever our intentions towards these wolves, how should we balance our responsibilities to the rest of nature-including, of course, the humans who live in the wolves' environs? Finally, what does our recognition of different kinds of moral value in red wolves imply for development, land use planning, and environmental policy?

The answers depend, in part, on the kind of moral value that we attribute to animals. We might, on the one hand, view animals as mere objects, biological mechanisms bereft of moral standing, as creatures to whose needs we are indifferent. We might, on the other hand, view animals as thinking creatures, many of which differ little from ourselves in their capacity to feel emotions and pain. In that case, animals assume a moral standing analogous to that of humans, and their needs must be accorded a high level of significance. Then again, we might also distinguish the moral value of charismatic megafauna (like horses and wolves) from that of microfauna and viruses (like zooplankton and HIV). We would do so in order to avoid conflating the moral value of creatures having vastly different characteristics, as well as to account for variance in the magnitude of human impacts upon them. Keeping this distinction in mind, we might reasonably argue that, on the basis of sapience alone, the moral value of horses outweighs that of HIV. Horses have, after all, a sophisticated neural system with which to perceive and conceive, and as a consequence, a demonstrable ability to form social bonds between themselves and other animals (including humans). Similarly, we might reasonably take action on behalf of a sapient and endangered species like wolves, since humankind has so negatively affected their individual and social well-being. This does not mean, however, that we should be indifferent to the state of zooplankton, a critical 


\section{Contested Moralities}

component of aquatic ecosystems. Rather our moral concern for zooplankton needs to be grounded in something other than sapience, such as the ecological function of plankton in the global food web.

\section{Value Paradigms}

Speaking very generally, our disposition towards the moral value of animals is encapsulated in value paradigms. A value paradigm is a conceptual map of moral value. It consists of a configuration of concepts (terms, definitions, distinctions, etc.) used to orient ourselves and guide our actions in the social and natural worlds. They help us navigate moral and social space by locating where we stand in relation to others. Deep ecology and ecofeminism are just two examples of environmental philosophies having especially sophisticated value paradigms (for example, see Naess 1989; Warren 1994). While value paradigms are constituted by a variety of concepts, I shall mention two common distinctions that shed light on the Dear and Symanski exchange. The first distinction is between anthropocentrism (human centred) and non-anthropocentrism (not human centred), the second between biocentrism (life centred) and ecocentrism (ecologically centred).

Anthropocentrism claims that moral value is located in Homo sapiens alone. Humans are therefore the locus of all intrinsic value-we are ends in ourselves, form self-contained moral communities, and have responsibilities only to one another. Non-human entities have only instrumental value, they are the means to human ends (Figure 1). Anthropocentrism is embedded in virtually all of our dominant ideologies, cultural practices, laws, policies, and regulations. Regrettably, it is akin to ethnocentrism, racism, sexism and other invidious ideologies in constructing essentializing dualisms and rigid value hierarchies, none of which is rationally defensible or ethically justifiable. Non-anthropocentrism holds that moral value extends beyond human beings into the natural world. Animals (and often the rest of nature) have intrinsic value, should be included in our moral community, and humans have ethical responsibilities to them. While non-anthropocentrism is frequently marginalized in policy discussions, it is tremendously important in animal and environmental ethics. It has a parallel importance in the animal rights and environmental movement, although the latter frequently speaks with an anthropocentric voice to avoid conflict within its own ranks, as well as to curry credibility amongst the general public and the politically powerful. ${ }^{\text {vii }}$ To paraphrase a popular bumper sticker, non-anthropocentrists believe 'humans are not the only species with moral value, they just act like it' (Naess 1989; Oelschlaeger 1991; Rolston 1994).

\section{Humans}

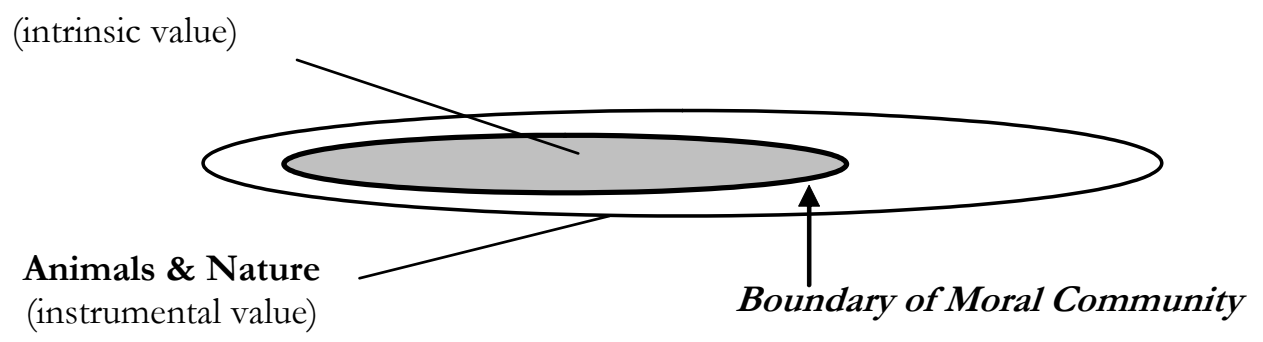

Figure 1. Anthropocentrism

The second distinction is between biocentrism and ecocentrism. Both biocentrism and ecocentrism are non-anthropocentric, and extend moral standing to the natural world. Yet they differ over the moral significance of nature's parts and wholes. Biocentrism emphasizes the parts, that is, individual 
plants and animals, claiming the moral value of each life-form are more significant than the abiotic things (e.g. rocks) and the ecosystems that form their habitats. So in the case of horses and wolves, it is the individual horse and wolf that is the locus of moral value. The species 'horse' (Equus caballus) has no moral value in and of itself, as it is but an aggregate of individuals. So too, ecosystems lack intrinsic moral value, although they are instrumentally valuable as the habitat in which individual animals live out their lives. Ecocentrism emphasizes wholes, that is, species and ecosystems. It differs from biocentrism by claiming the locus of moral value is in ecological wholes, not in the particular plants or animals that constitute those wholes. Individuals are primarily of instrumental value as functional constituents of a greater whole. All other things being equal, animals of a particular species are fungible, that is, one is as good as another as long as they perform their proper function in the ongoing evolution of their species and associated ecosystems (Figure 2). As a consequence of this line of reasoning, an individual horse has no intrinsic moral value (Fox 1990; Rolston 1988; Taylor 1986).

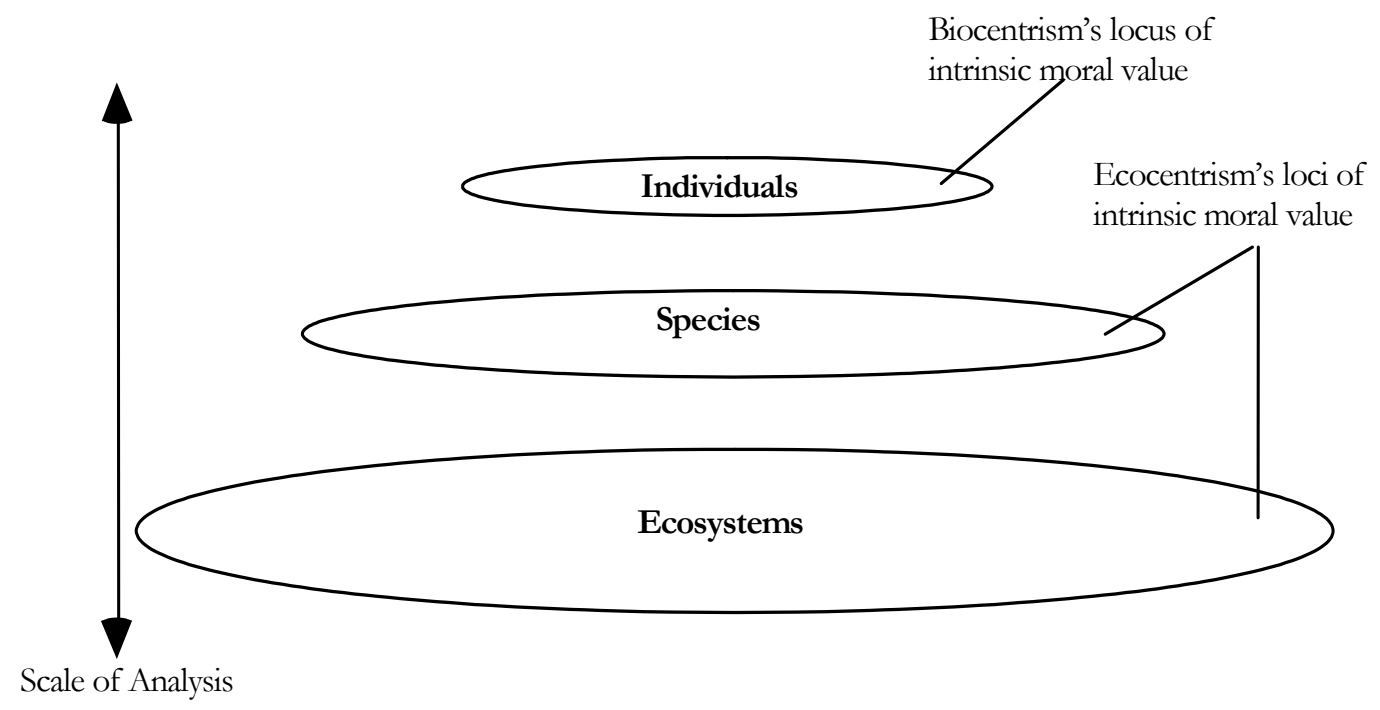

Figure 2. Biocentrism and Ecocentrism

This discussion of moral value and value paradigms may seem abstract, but it illuminates Dear and Symanski's exchange. They disagree on the appropriate treatment of wild horses in Australia, yet both assert a non-anthropocentric belief in the moral standing of the natural world. The tension between their views reflects the moral significance they attach to nature's parts and wholes. Dear's concerns are for the wild horses themselves, Symanski's for the ecosystem in the Australian outback. Dear's paradigm thus tends to biocentrism, Symanski's towards ecocentrism. Unfortunately, neither Dear nor Symanski justify their value paradigms, preferring instead to let stand the unarticulated presuppositions in their arguments. Nor do they offer coherent critiques of the other's paradigm. Dear hints at a critique when he charges Symanski with the 'domination of nature', and Symanski does the same when he indicts Dear's ancestors for environmental crimes against biodiversity. Even so, both critiques fail to hold water. Dear directs his charge at anthropocentrism, a paradigm Symanski rejects, and Dear cannot be held culpable for his ancestors' actions in the way that Symanski suggests. Moreover, both authors speak past each other's moral concerns. By ignoring biodiversity, Dear's argument inadequately addresses Symanski's ecocentric concerns. By simply asserting the normative power of his ecological expertise, Symanski fails to address the moral concerns of biocentrists such as Dear. ${ }^{\text {viii }}$ 


\section{Contested Moralities}

\section{Geocentrism}

When we consider individual animals like horses, humans and wolves, biocentrism makes powerful claims on our moral sensibilities. Simultaneously, ecocentrism makes equally powerful claims regarding ecological wholes - species, populations, and ecosystems - which are the necessary contexts that sustain individual lives. Both biocentrism and ecocentrism, therefore, offer insights to our moral relations with animals and the rest of nature. How are we then to decide between the two? Fortunately we need not do so. We have the alternative of finding a deeper, less binary understanding. The problem with biocentrism and ecocentrism is not their insights, but their conceptual structure. They are value paradigms constructed as ideal typologies, and as such, are too rigid to adequately understand our earth. Our world is not only more complex than we know, but more complex than ideal typologies can ever represent. I think the root of this typological error lie in transforming a distinction between life and ecologically centred valuations into a dichotomous mode of moral reasoning. Such typologies are often a source of mischief, manifesting themselves in the form of misinterpretations and ill-conceived actions. ${ }^{\text {ix }}$ By committing to either biocentrism or ecocentrism, we sacrifice the insights of one for the other, and from my point of view as a hermeneutically informed ethicist, this dualistic choice is forced, unnecessary and counterproductive.

I would suggest we think about moral value in a more pluralistic and contextual way. Geocentrism (earth centred) is the term I use for a paradigm locating moral value in both the parts and the wholes of the earth. Individuals, species, and ecosystems have concurrent moral value, that is, they are intrinsic ends in themselves, as well as an instrumental means to other ends (Figure $3 \mathrm{a}$ and $3 \mathrm{~b}$ ). To return to our previous examples, both horses, humans and wolves have moral standing in the geocentrist's ethical community. Moreover, as both individuals as well as ecological and social communities, the geocentrist gives equal consideration to the moral significance of their needs. When we manage the population of any of these beings, we immediately face moral questions regarding the consequence of our policy. We cannot duck our ethical responsibilities by arbitrarily barring or permanently privileging some members of the moral community. Similarly, because these beings have concurrent moral value, we should not arbitrarily and capriciously sacrifice the well-being of some individuals or collectives (say, an individual horse or a population of horses) to the well-being of others (say, a native biome, the interests of a corporation, the collective interests of a human community). Instead, we should identify the relevant moral values at stake, and then ethically justify our proposed course of action.

Co-Values

(concurrent moral values)

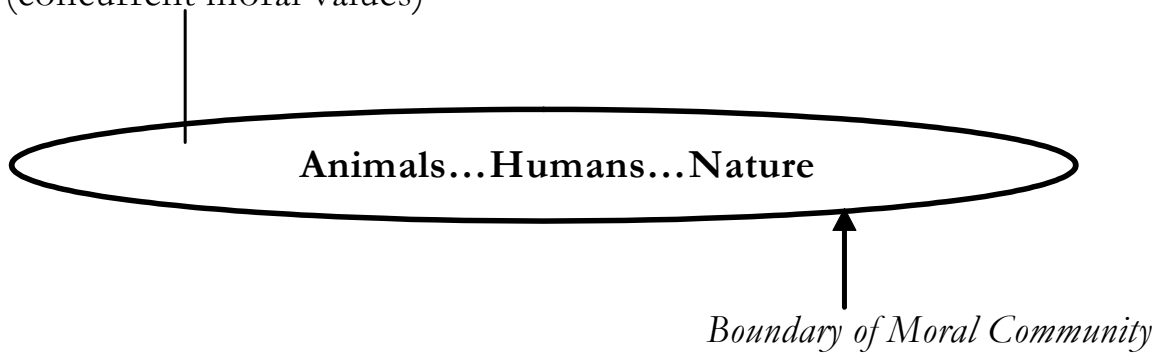

Figure 3a. Geocentrism 


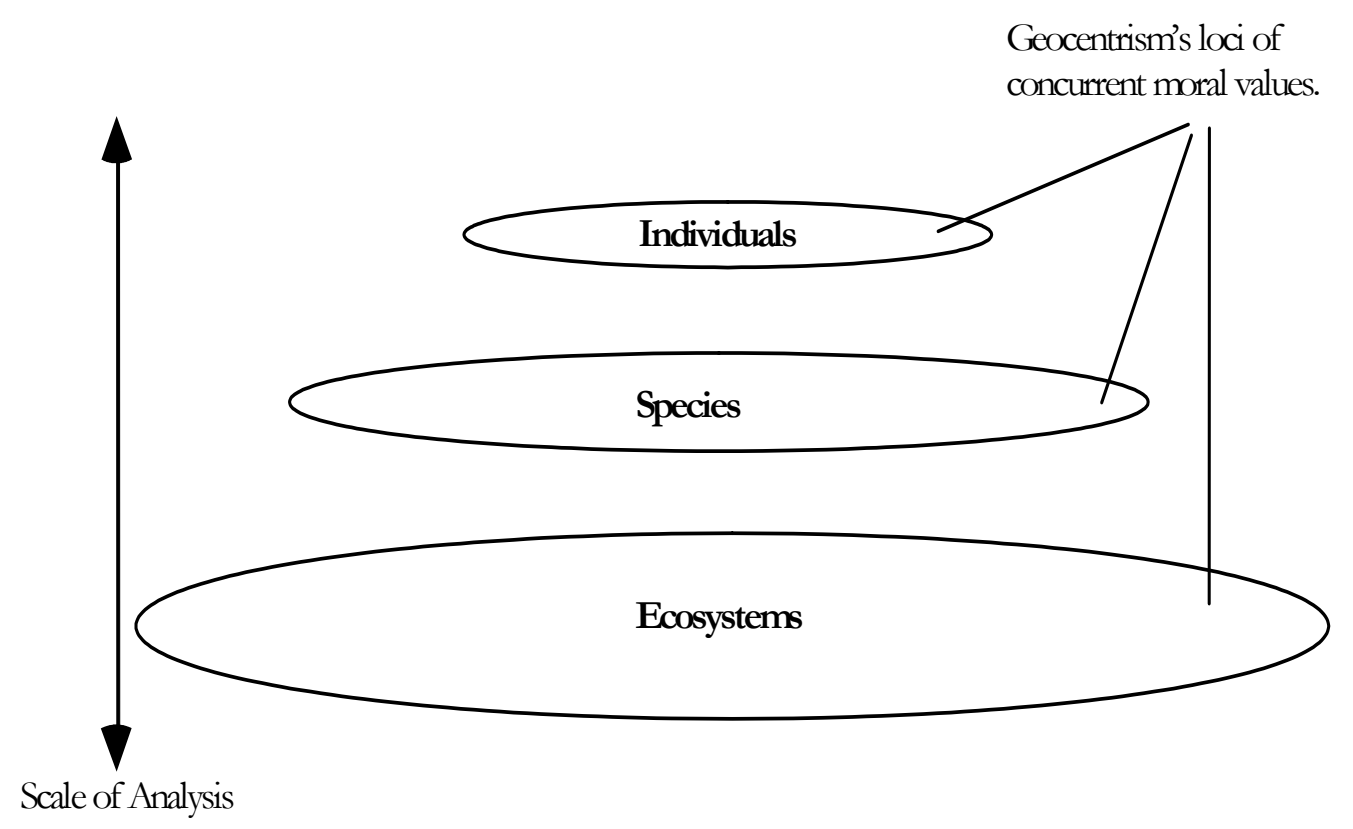

Figure 3b. Geocentrism and the loci of concurrent moral values

In addition, geocentrism is not a typology which acontextually decides who has moral standing and what moral values are relevant. It is a true conceptual map-a situationally specific configuration of value-relevant concepts. As a conceptual map, geocentrism should strive to produce place-sensitive evaluations of moral problem. As part of this place sensitivity, we must recognize that components of ethical inquiry — our moral problems, scales of analysis, the beings and things involved in our interpretations - will shift over time and space. These shifts make ethical affairs inherently complex and contextual, and as a result, the salient moral values will differ in degree and kind.

To concretize this point, consider some of the value-based ethical issues involving exotic species. The moral problem of exotic species threatening biodiversity does not arise when species remain in their evolutionary and geographical niche. In this case there are no exotic species, and the ecological values of biodiversity are not threatened. Nature is in constant flux, however, and the interaction of species outside the bounds of their usual niches is inevitable. When exotic species do colonize an area, they frequently diminish biodiversity on a historic time-scale. On an evolutionary time-scale, reconfigurations of trophic relations and coevolution may even things out. Still, in the time-scale of human beings, exotic species do pose difficult moral problems. Because the loss of biodiversity affects the livelihoods and habitats of humans and wildlife alike, the consequences of a substantial change can be quite severe and wide-ranging. The overgrazing of the Australian outback by rabbits is a well-known illustration. In cases such as these, whose well-being do we attend to, the indigenous life-forms or the exotic life-forms? Do we focus our ethical concern on individual animals, ecological wholes, or both? Does it make a difference if those life-forms are sentient or sapient? Is it less permissible to control exotic species if they are a sapient life-form, than if they are an nonsapient insect, plant, bacteria, or virus? Can we really equate the control of an aquatic 'weed', like purple loosestrife in Minnesota, with the slaughter of wild horses in Australia? Are there no morally relevant differences between the two cases to help us adjudicate this conflict? Moral considerations are further complicated when humans are responsible for the introduction of exotic species, more so in the modern era as the rate of anthropogenic environmental change has exceeded the background rates for biogeographical interaction and natural extinctions. If humans are culpable for these 


\section{Contested Moralities}

introductions, should we not bear the burden of correcting the situation? Should this correction be made at the expense of extant exotics, especially if those exotics are sapient creatures? These are not the only important questions, but for the geocentrist, they are necessary contextual considerations that must precede any attempt to clarify the moral problem of biodiversity.

By acknowledging a fluid mix of concurrent moral value throughout the world, geocentrism yields a richer conceptual map of values, one that is more complex and contextual than those of biocentrism or ecocentrism. As a consequence of this complex contextuality, a geocentrist cannot make a priori decisions about a being or thing's moral standing or significance without taking account of the particulars of a place. So in Dear and Symanski's case, (s)he cannot decide ahead of time what trumps or subserves the moral status of horses, people, the outback, or any other entity. Instead, (s)he must make the wisest judgment possible given the weight of reasons, the preponderance of evidence, and the characteristics of the site and situation.

How might geocentrism help in evaluating the wild horse 'problem'? The adoption of geocentrism in environmental policy and politics will make environmental problems more difficult to resolve, at least according to the canons of value-free and anthropocentric policy science. Because the wellbeing of animals and the rest of nature is added to the normal play of human-focused resource management, environmental planning can be complicated. At worst, geocentrism might be misconstrued as pitting the well-being of humans against other animals and nature. Even so, I think there are several ways in which geocentrism contributes positively to the resolution of environmental conflicts in general, and the wild horse problem of Australia in particular.

First, geocentrism can help clarify the nature of environmental conflicts. The controversy over wild horses is not a matter of science versus emotion, as Symanski implies, but of underlying differences in the moral valuation of animals. Until this moral dimension is addressed, scientistic resource management will fail to adequately comprehend or attain a just and reasonable resolution to environmental problems. Second, geocentrism legitimates the existence and diversity of moral values in environmental conflicts. From a geocentric perspective, both the wild horses and native biomes of Australia have moral value. Arguments for preserving these horses cannot be dismissed as "offthe-wall", since these involve genuine ethical concerns about the standing and significance of animals in environmental policy. Third, geocentrism can help mediate the conceptual gridlock of these conflicts. Dear and Symanski, not to mention animal rights activists and ecologists, bring salient moral insights to the problem of exotic animals and biodiversity. Whereas a biocentric or ecocentric view pits these groups against one another, a geocentric view recognizes the salience of each, and clears the way for the creation of a shared moral vision that respects the human and nonhuman members of our moral community. Fourth, geocentrism helps generate contextually appropriate evaluations and actions regarding environmental problems. Resisting categorical judgments based on inflexible norms of value, a geocentrist will try to balance our moral responsibilities to wild horses with those to native biomes. Only after weighing the various gains and losses will (s)he recommend or take appropriate action (or inaction). Given that much of Australia's Northern Territory is ill suited to the grazing and migration pressures of horses, and that the losses to Australian (and global) biodiversity is large, I suspect Symanski is correct in calling for the elimination of wild horses. But this is not to say that Dear is "wrong". The site is also the home of Australia's 'mustangs', and an adequate ethical assessment should include our moral responsibilities to these animals. In this case, Dear is correct in calling Symanski to account for disregarding the moral standing of these creatures. 
Overall, recognizing the moral concerns of all the 'stake-holders' in such disputes requires a political process and academic environment that explicitly legitimates moral discourse in the creation and application of environmental policy. It also requires adequate time and mutual commitment to dialogue in the search for a deeper and less dichotomous moral understanding. Judging from Symanski's narrative, animal rights activists, resource professionals, and other pressure groups made their views known, but an ethical dialogue was never established. If this dialogue is not started, advocates of the Brumbies preservation or extermination will continue to vilify and obstruct one another to the detriment of both horses and biodiversity. Geocentrism can help stakeholders extricate themselves from the conceptual traps that, especially in difficult circumstances requiring hard choices, foment dogmatic intransigence.

\section{Cultivating Geocentrism}

At this point I want to shift our focus to the theoretical, methodological and practical significance of geocentrism. Articulating the full range of these implications is a collective task, and I shall not try to do so here. What I will do is point out several broad directions in which geocentrism might expand the moral horizons of geographical ethicists, moral philosophers, and social theorists. Although this is a partial account, in terms of both point-of-view and coverage, I believe these directions will deepen our moral account of animals, as well as of geography.

First, geocentrism foregrounds axiology (the study of moral value) in geographical accounts of the animal estate. By paying attention to axiology, we are heeding Holmes Rolston's injunction to "make latent value judgments explicit" (Rolston 1994, 32). The Dear/Symanski debate is just one instance of the pervasive character of moral value in disputes over animal well-being. Unfortunately, our value paradigms regarding animals are usually presuppositional, influencing our moral sensibilities in ways we may not intend or fully understand. When the axiology is anthropocentric, the consequences are likely to be deplorable. Until recently, the value paradigm of anthropocentrism was 'naturalized' in geographic inquiry, that is, it was an unarticulated presupposition that passed unrecognized, unacknowledged, and unproblematized. Fortunately the growing literature in the "“new' animal geography" (Philo 1995, 657) is demystifying the representational and spatial practices of anthropocentrism. Yet while necessary, this emphasis is not sufficient. What is lacking from this otherwise cogent and passionate literature is the justification of a non-anthropocentric moral vision. This is a matter of special concern because justification-defending a vision of how we ought to live with others (including animals) — is at the heart of moral inquiry.

As one referee of this manuscript kindly reminded me, animal geographers do often refer to alternative animal ethics as a means of explaining their own positionality (e.g., animal rights, ecofeminism). In addition, their discussion of intrasocial and interspecies oppressions, social/animal geographies of inclusion and exclusion, and transspecies social and urban theory, bespeaks a vision of a more nurturing and egalitarian relationship with animals (see especially Emel 1995 ; Philo 1995; Wescoat 1995; Wolch, West, and Gaines 1995). Still, the justification for this laudable vision is absent. Nowhere are we afforded compelling reasons for why we should care about the fate of animals: this care is simply assumed. It was not these authors' intention to formulate a moral defense of animals. Yet I think the ramifications of this absence remain profound. Without a defense, the intentions and/or outcomes of geographic research into animal well-being will remain marginalized, having little effect inside or outside geography. Without justifying the moral standing and significance of beings (individual and collective, human and non-human), as well as including some reference to the concept of moral value (however it may be named and framed), social and moral 


\section{Contested Moralities}

theory becomes relativized and ineffectual. Social theories that reduce ethical affairs to matters of power or property, and moral theories that sidestep questions of axiology, share a fundamental vulnerability on this point. By providing a justification, geocentrism points in one fruitful direction for redressing this lacuna.

Second, geocentrism highlights how anthropocentrism disprivileges not only animals, but also human beings themselves. Non-anthropocentrists draw parallels between anthropocentrism on the one hand, and ethnocentrism, racism and sexism on the other. This is well and good, but again, is insufficient as it fails to reveal the complex genealogies of anthropocentrism in the world of humans. We treat anthropocentrism as monolithic and fixed, an absolute dichotomy between humans and the natural world, and the definitive product of European religion, science and technology (for the classic statement, see White 1968). In so doing, we fail to see how anthropocentrism constitutes 'humanity' and thence the boundaries of moral community, a project 'shared' by many nonEuropeans-premodern, modern and postmodern. To appreciate these genealogies we need an expanded sense of anthropocentrism, as more than an analogue to human inequality, but as an active practice and central justification for human oppression itself. Other scholars have 'extended' the concepts of colonization and imperialism to expose the dynamics of power in our relationship to nature (Kothari 1990; Katz 1997). I think it is time, that we reverse the flow of argument, and use an expanded understanding of anthropocentrism to explore the ethics-laden power differentials in our social relations.

To espy the activity of anthropocentrism can be difficult, for it mystifies its presuppositions and outcomes by claiming they are the 'natural order' of things, which is to say it normalizes itself by making it seem 'natural'. We typically take this to mean a human/nature dichotomy. But anthropocentrism is more flexible that this, naturalizing the moral exclusion of some human beings by 'animalizing' their natures. Since only 'fully' human beings are accorded moral recognition and treated as ends unto themselves, other humans can be use as means to human ends, as 'animals'. The patriarch's claim that women are imperfect men, the slaver's belief that Africans and new world Indians were not (fully) human, and the Nazis' claim that Jews were subhuman, are illustrative examples. These examples are underlain by a common value paradigm that naturalizes inter/intraspecies privilege for some (e.g., men, whites, Aryans, 'humanity') while animalizing and disprivileging others (e.g., women, blacks, Jews, 'beasts'). Through plural incarnations it simultaneously devalues people through discourses like ethnocentrism, racism and sexism, even as it devalues animals and the rest of nature through the discourses of speciesism and naturism (Figure 4).

\begin{tabular}{|c|c|}
\hline \multicolumn{2}{|c|}{ ANTHROPOCENTRISM } \\
\hline By Excluding Some Humans & By Excluding Non-Humans \\
\hline — Ethnocentrism & - Speciesism \\
\hline — Racism & — Naturism \\
\hline - Sexism & \\
\hline
\end{tabular}

Figure 4. Expanded Sense of Anthropocentrism

The key to understanding this is to see anthropocentrism as engaged in a discursive practice of othering. Anthropocentrism constitutes 'others' by creating dualistic categories of persons and things that are arrayed into rigid value hierarchies. This practice might seem confusing and contradictory if anthropocentrism is conceptualized as an ideal type. By 'definition' anthropocentrism accords moral value to humans, so how could it simultaneously devalue other humans? Yet viewed as a dynamic 
discursive practice, anthropocentrism constitutes a particular meaning of 'human'. What it means to be human shifts over time and space, and we cannot use our own definition of humanity as a standin for the empirical meaning of 'human' in anthropocentric discourses. Anthropocentrism provides criteria for classifying animals and some humans as holding lesser or no moral value, eliminating their membership in 'our' moral community, and erasing our moral obligations to those so excluded (Figure 5). To appropriate the language of Derek Gregory, anthropocentric othering "dispossesses” animals of their moral value through "strategies" of classifying, arraying, naming, and marginalizing (see Gregory 1993, especially 168-174).

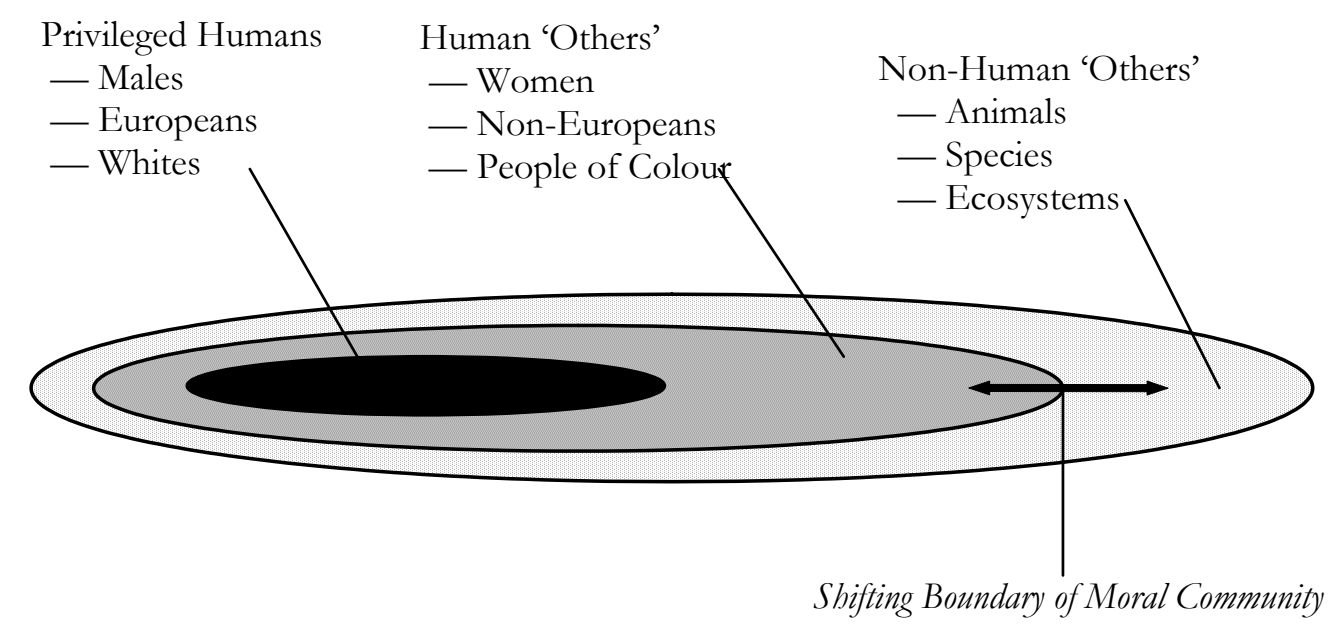

Figure 5. Anthropocentric 'Othering'

When we attend to the geographic and historical forms and practices of anthropocentrism, we can develop a more dynamic and situated understanding of its power to shape the moral order.

Geocentrism contributes to this understanding by revealing and contesting anthropocentrism's use of species, social and spatial 'difference' as an invidious typology for moral value. Note that I am not arguing that anthropocentrism 'hurts us all' because it indirectly affects the material well-being of people. Nor am I arguing that the oppression of animals, humans and nature is simply linked through 'metaphor' or 'logic', although as discursive practices, both play a role in constituting our moral landscapes. Rather I am making a "dreaded comparison" between the operation of anthropocentrism in the spheres of animal and human life, a comparison that challenges the most pervasive 'ideology' of the human and natural sciences (my emphasis, from Spiegel 1988). Anthropocentrism is more differentiated, complex, widespread, and nefarious than we realize, which is an invitation for all of us to explore its plural forms, and when appropriate, rethink our approval of its positions (for example, Pepper 1993, xi).

Third, geocentrism illustrates how geography helps generate alternatives to the extremes of ethical universalism and relativism. Universalism maintains that absolute moral standards apply to everyone regardless of place, time or context, while relativism holds that all ethics are relative to personal taste or custom. Both positions disempower our faculties of ethical reflection, the first by eliminating the contextual elements that make ethics more than an exercise in formal logic, the second by robbing us of the necessary practice of evaluative moral judgment. We cannot find moral guidance in abstract principles alone, or by ignoring the moral dimensions to our individual and collective lives. Universalism and relativism are a false dichotomy, a dualism we are better served to put behind us. 


\section{Contested Moralities}

What we require instead is a situated moral understanding that is sensitive to the particulars and context of moral problems, but does not sacrifice its ability to adjudicate between better and worse accounts of our moral responsibilities in concrete sites and situations. Geography contributes to this alternative by providing contextual and conceptual insights for moral reasoning, insights we need to make discriminating judgments about our ethical responsibilities in the world. To accept these insights from geography, however, we need to substantially alter our engagement with the dominant practices of analytic moral philosophy and rediscover our own 'indigenous' moral resources. Analytic philosophy remains the prime influence on anglophone philosophy in the twentieth century, and by extension, on the ethics produced by academic philosophers in the Anglo-American world. Conceived as a 'science of thought', its practitioners sought certitude in knowledge through logical analysis and deductive, axiomatic reasoning. The universalist/relativist dualism is an enduring feature of the faith and/or despair that analytic philosophers hold out for certainty in ethical matters (see von Wright 1993, chapters 1-2; Bernstein 1991). Analytic moral philosophy emphasizes the deductive use of a principle (e.g., the universalizability principle, the principle of relativity) to adjudicate all moral problems. It reasons about moral issues from the top down, from an abstract principle to empirical particulars, with the intent of producing incorrigible answers for all similar cases. This approach presupposes the transgeographic (timeless and placeless) validity of its principles, the adequacy of a priori theorizing about concrete circumstances, and a primary commitment to deductive rigour irrespective of practical insight. While these presuppositions promote analytic rigour, they do little to produce situated moral wisdom (Toulmin 1986).

Once we drop the commitment to uniform transgeographic principles, a priori theorizing, and logic chopping, we can approach moral problems with greater contextual sensitivity, allowing for a greater play and reciprocity between principles and particulars. For instance, we may hold a plurality of moral principles, make interpretive distinctions between diverse sites and situations in lived moral experience, flexibly apply a range of principles in the manner most appropriate to the circumstances, and adjudicate moral problems on a case-by-case basis. Contrary to the fears of analytic ethicists, we do not sacrifice general principles, edifying precedents, or conceptual rigour through a contextual approach. Rather we forestall the overinterpretations that arise from imposing theoretical grids onto the landscape of our moral concerns (Lynn 2000; see Miller 1996; Smith 1991; Toulmin and Jonsen $1988)^{x i}$. Using geographic insights into scale, site and situation, I construct the axiology of geocentrism as context-sensitive (Lynn 1998). Other geographers have taken a similar approach with the concepts of justice, place and space (Sack 1997; Smith 1998). Nothing prevents geographers from doing the same with respect to other ethical matters in geographic inquiry.

Finally, by signifying the moral power of geography, geocentrism encourages the development of diverse forms of geographical ethics. For some years now I have distinguished between moral geographies (ethical discourses in geography), geographical ethics (the study of ethics in geography), and geoethics (my account of geographical ethics). Geocentrism is one of a triad of primary concepts that includes hermeneutics and casuistry, which together generate the principles and methods of geoethics. I make these distinctions not only to acknowledge the legitimate plurality of ethics in the geographical tradition, but also to differentiate ethics that are more or less friendly to the worlds of animals, humans and nature. Not all geographical ethics will acknowledge the plurality of moral values that exist in animals and the rest of nature. While a diversity of perspectives (e.g., feminist, poststructural, postcolonial, etc.) should continue to inform geographical ethics, I do hope the resulting theories, methods and practices are increasing geoethical in spirit. Foregrounding axiology, widening the meaning of anthropocentrism, and emphasizing the need to situate moral 
knowledge are important guidelines in cultivating an ethic that to avoids categorical and transgeographical errors. ${ }^{\text {xii }}$ We already have compelling reasons to reject anthropocentrism. It is unreasoning and invidious: conceptually incoherent, consequentially abhorrent, a threat to biodiversity and ecological function, a distorting influence on personal and collective identity, and a model for social oppression. What we need now is positive moral guidance to take us beyond anthropocentrism. As a powerful resource in the development of a more contextual and geocentric account of ethics, geographic insights can help us avoid not only the pitfalls of anthropocentrism, but also the scale-insensitive rigidities of biocentrism and ecocentrism.

\section{Caveat}

Finally, a caveat. I may be guilty of overinterpreting Dear and Symanski. As readers we can only infer an author's intentions. I read their debate from the standpoint of a geocentrist especially concerned about humanity's moral relationship to animals and wild nature. Their exchange reflects a sensibility (a disposition in thought and action) rather than a fully articulated argument, and my reading may not do justice to their more considered understanding of animal's moral value. My purpose here is not to pin a determinative reading on either author, but rather to employ their exchange to reflect upon our ethical relationship with the animal world. If I have mistaken their meanings and implications, I will be pleased to stand corrected.

\section{Acknowledgements}

I would like to thank Carville Earle, Iain Hay, Helga Leitner, Fred Lukermann, Deborah Martin, Laura Pulido, Roger Miller, Eric Sheppard, and two anonymous referees for their helpful critiques. Casey Miller and Copper Sheppard inspired this work, and a special debt is owed Anne D'Alleva. All shortcomings are, of course, my own.

\section{Notes}

i Symanski's use of horses was shrewd. The horse has a historically deep, culturally rich, and emotionally resonant place in our society, a fact that makes the killing of wild horses by humans controversial (for example, Budiansky 1997; Edwards 1991, 1995; Roberts 1997).

ii I am using the term 'postmodern' in an intentionally broad manner, referring to a family of perspectives that emphasize postpositivist understandings of discourse, science and social theory. This 'family' includes hermeneutics, feminism, postcolonialism, poststructuralism, etc. Used in this manner, postmodernism signals a historical disjuncture in modernist assumptions, what Zygmunt Bauman calls "modernity without illusions", that is, a reflective interrogation of individual and collective presuppositions about reason, representations, and power (Bauman 1993, 32).

iii This state of affairs is changing, even if the transition from amoral social and physical science to ethically informed research is ponderously slow (for examples see Bauman 1993; Zimmerman 1994; Benton 1993; Langley 1989; Simmons 1993; Cheney 1989). Within geography, Dear and Symanski's engagement with animal ethics was (at the time) rare and refreshing, and I commend them for it.

iv The first horses arrived in Australia in 1788, one ramification of English colonization. The name 'Brumby' is reputedly derived from James Brumby, a military officer of New South Wales who may have left his horses behind when he was relocated to Tasmania in 1804. Like the North American 'Mustang', Brumbies are a mixed breed of feral horses that include Arabian and English thoroughbreds, draught horses, and others. Used as agricultural and mining labour in the Murry-Darling Rivers watershed in the 1800s, these horses were either abandoned or escaped into the outback. By the 1960s their herds numbered in the tens of thousands, and Australian authorities began organizing 'culling' operations for both economic and ecologic reasons. 


\section{Contested Moralities}

Culling generated outrage and protest from animal welfare and heritage organizations, and the practice remains extremely controversial (Edwards 1994, 218-219; Symanski 1994, 252-262).

v The quotation is from the Socrates of Plato's Republic, Book 1:352d.

vi Humans are not the only sapient creatures on earth, and this can complicate the ethics of population management (see Rolston 1990).

vii To a degree this is understandable, since in what passes for political discourse today, many persons are altogether ignorant or sceptical of moral arguments, much less moral arguments regarding animals and nature. viii Symanski does refer to himself as a biocentrist (Symanski 1994: 301). This is not surprising or contradictory to my point, as many academics use the term biocentrism as a catchall for non-anthropocentric beliefs. In a similar way, Rolston uses the term ecocentrism in a nuanced manner, combining what I term both ecocentrism and geocentrism. The polyvocality of terms can be off-putting to those unfamiliar with an intellectual terrain, but it is only problematic when we ignore an author's contextual voice, and insist on or impose a singular, essential meaning to their terms. Unlike Rolston, I distinguish between ecocentrism and geocentrism to tease apart the unnecessary confusions over particular individuals and ecological wholes in animal and environmental ethics.

ix For a distressing example of the mischievousness of ideal typologies, see the speciesist and antinaturist work of David Pepper (Pepper 1984, 1993, 1996).

${ }^{x}$ My own experience in teaching is instructive on this point. My otherwise kind and intelligent students are frequently puzzled by moral concerns, whether for animals or for human beings. Inculcated into the moral relativism of market metaphors and therapeutic self-absorption, they frequently ask the following questions: "Why should we care about animal well-being; so what if they are "commodified, controlled and consumed" (Wolch and Emel 1995, 632); what is wrong with unequal social/species/spatial power? For that matter, as long as I get what I want, why should I care about distinctively human inequalities (like ethnocentrism, racism, and sexism), much less the parallels between the oppression of animals and human social groups'? xi My use of the word 'we' is not intended to be hegemonic or universalizing. Rather, I am avoiding the linguistic distancing of the word 'one', and in so doing, stressing the need for like-minded 'geoethicists' to reflect on alternatives to analytic moral philosophy as a community of scholars.

xii 'Situated moral knowledge' has both verbal and conceptual resonances with Donna Haraway's conception of "situated knowledge" (Haraway 1991). Haraway's search for an epistemological alternative to the objectivity and social construction in science parallels my own search for a contextual alternative to universalism and relativism in ethics.

\section{References}

Aristotle. 1985. Nicomachean Ethics. Translated by T. Irwin. Indianapolis: Hackett.

Bailey, James A. 1984. Principles of Wildlife Management. New York: John Wiley \& Sons.

Bauman, Zygmunt. 1993. Postmodern Ethics. Cambridge: Blackwell.

Benton, Ted. 1993. Animal Rights and Social Relations. In The Politics of Nature: Explorations in Green Political Theory, edited by A. Dobson and P. Lucardie. New York: Routledge.

1993. Natural Relations: Ecology, Animal Rights and Social Justice. London: Verso.

Bernstein, Richard J. 1991. Beyond Objectivism and Relativism: Science, Hermeneutics and Praxis. Philadelphia: University of Pennsylvania Press.

Blaut, James M. 1993. The Colonizers Model of the World: Geographical Diffusionism and Eurocentric History. New York: Guilford Press.

Budiansky, Stephen. 1997. The Nature of Horses. New York: Free Press.

Cheney, Jim. 1989. Postmodern Environmental Ethics: Ethics as Bioregional Narrative. Environmental Ethics 11 (Summer):117-134.

Daly, Herman E., and Kenneth N. Townsend, eds. 1993. Valuing the Earth: Economics, Ecology, Ethics. Cambridge: MIT Press.

Dear, Michael. 1994. Who's Afraid of Postmodernism? Reflections on Symanski and Cosgrove. Annals of the Association of American Geographers 84 (2):295-300. 
Demeritt, David. 1994. Ecology, Objectivity, and Critique in Writings on Nature and Human Societies. Journal of Historical Geography 20 (1):22-37.

- 1994. The Nature of Metaphors in Cultural Geography and Environmental History. Progress in Human Geography 18 (2):163-185.

Edwards, Elwyn H. 1991. The Ultimate Horse Book. London: Dorling Kindersley.

- 1994. The Encyclopedia of the Horse. London: Dorling Kindersley. . 1995. Wild Horses. Hastings, Minnesota: Voyageur Press.

Emel, Jody. 1995. Are You Man Enough, Big and Bad Enough: Ecofeminism and Wolf Eradication in the U.S. Environment and Planning D: Society and Space 13 (6):707-734.

Emel, Jody, and Jennifer Wolch. 1995. Animals and Social Theory. Paper session at the annual meeting of the Association of American Geographers, Chicago, 16 March 1995.

FitzSimmons, Margaret. 1989. The Matter of Nature. Antipode 21 (2):106-120.

Fox, Warwick. 1990. Toward a Transpersonal Ecology: Developing New Foundations for Environmentalism. Boston: Shambahla Press.

Gaard, Greta, ed. 1993. Ecofeminism: Women, Animals, and Nature. Philadelphia: Temple University Press.

Gare, Arran E. 1995. Postmodernism and the Environmental Crisis. New York: Routledge.

Glacken, Clarence J. 1967. Traces on the Rhodian Shore: Nature and Culture in Western Thought from Ancient Times to the End of the Eighteenth Century. Berkeley: University of California Press.

Gregory, Derek. 1993. Geographical Imaginations. Cambridge: Blackwell.

Haraway, Donna J. 1991. Simians, Cyborgs, and Women: The Reinvention of Nature. New York: Routledge. 1991. Situated Knowledges: The Science Question in Feminism and the Privilege of Partial Perspective. In Simians, Cyborgs, and Women: The Reinvention of Nature. New York: Routledge.

Herodotus. 1996. The Histories. Translated by A. D. Selincourt. Revised, with Introductory Matter and Notes by John Marincola ed. Suffolk: Penguin Books.

Ingold, Tim, ed. 1988. What Is An Animal? London: Unwin Hyman.

Johnston, R. J. 1997. Geography and Geographers: Anglo-American Human Geography Since 1945. Fifth ed. London: Arnold.

Katz, Eric. 1997. Imperialism and Environmentalism. In The Ecological Community: Environmental Challenges for Philosophy, Politics and Morality, edited by R. S. Gottlieb. New York: Routledge.

Kellert, Stephen R. 1996. The Value of Life: Biological Diversity and Human Society. Washington, DC: Island Press. Khaldun, Ibn. 1981. The Muqaddimab; An Introduction to History. Translated by F. Rosenthal. Edited by N. J. Dawood. Princeton: Princeton University Press.

Kothari, Rajni. 1990. Environment, Technology, and Ethics. In Ethics of Environment and Development: Global Challenge, International Response, edited by J. R. Engel and J. G. Engel. Tucson: University of Arizona Press.

Langley, Gill, ed. 1989. Animal Experimentation: The Consensus Changes. New York: Chapman \& Hall.

Livingstone, David N. 1992. The Geographical Tradition: Episodes in the History of a Contested Discipline. Oxford: Basil Blackwell.

Lynn, William S. 1995. Geography, Value Paradigms, and Environmental Justice. Newsletter of the Society for Philosophy and Geography 1 (2):2-4. 1997. Geography's Moral Turn, Paper for the 'Geography and Ethics' session at the Annual Research Conference of the Royal Geographical Society/Institute of British Geographers, University of Exeter, 8 January 1997. 1998. Animals, Ethics and Geography. In Animal Geographies: Place, Politics and Identity in the NatureCulture Borderlands, edited by J. Wolch and J. Emel. London: Verso.

1998. Contested Moralities: Animals and Moral Value in the Dear/Symanski Debate. Ethics, Place and Environment 1:223-242.

- 2000. Geoethics: Ethics, Geography and Moral Understanding. Doctoral Dissertation, Department of Geography, University of Minnesota, Minneapolis.

MacIntyre, Alasdair. 1966. A Short History of Ethics. New York: MacMillan.

Mack, Arien. 1995. In the Company of Animals [Special Issue]. Social Research 62 (3). 


\section{Contested Moralities}

Mazur, Laurie Ann, ed. 1994. Beyond the Numbers: A Reader on Population, Consumption, and the Environment. Washington, DC: Island Press.

Midgley, Mary. 1984. Animals and Why They Matter. Athens: University of Georgia Press.

- 1995. Beast and Man: The Roots of Human Nature. London: Routledge.

Miller, Richard B. 1996. Casuistry and Modern Ethics: A Poetics of Practical Reasoning. Chicago: University of Chicago Press.

Naess, Arne. 1989. Ecology, Community and Lifestyle: Outline of an Ecosophy. Cambridge: Cambridge University Press.

Noske, Barbara. 1997. Beyond Boundaries: Humans and Animals. Montreal: Black Rose Press.

Oelschlaeger, Max. 1991. The Idea of Wilderness: From Prehistory to the Age of Ecology. New Haven: Yale University Press.

O'Neil, Onora. 1996. Towards Justice and Virtue: A Constructive Account of Practical Reasoning. Cambridge: Cambridge University Press.

Outhwaite, William, and Tom Bottomore, eds. 1993. Blackwell Dictionary of Twentieth Century Social Thought. New York: Blackwell.

Pepper, David. 1984. The Roots of Modern Environmentalism. Beckenham: Croom Helm.

—. 1993. Eco-Socialism: From Deep Ecology to Social Justice. London: Routledge. 1996. Modern Environmentalism: An Introduction. New York: Routledge.

Philo, Chris. 1995. Animals, Geography, and the City: Notes on Inclusions and Exclusions. Environment and Planning D: Society and Space 13 (6):655-681.

Regan, Tom. 1983. The Case for Animal Rights. Berkeley: University of California Press.

Roberts, Monty. 1997. The Man Who Listens to Horses. New York: Random House.

Rolston, Holmes, III. 1988. Environmental Ethics: Duties To and V alues In the Natural World. Philadelphia: Temple University Press.

1990. Science-Based Versus Traditional Ethics. In Ethics of Environment and Development: Global Challenge, International Response, edited by J. R. Engel and J. G. Engel. Tucson: University of Arizona Press.

- 1994. Conserving Natural V alue. New York: Columbia University Press.

Runes, Dagobert D., ed. 1982. Dictionary of Philosophy. Revised ed. Savage: Rowman \& Littlefield.

Sack, Robert. 1997. Homo Geographicus: A Framework for Action, Awareness, and Moral Concern. Baltimore: Johns Hopkins University Press.

Shepard, Paul. 1996. The Others: How Animals Made Us Human. Washington, DC: Island Press.

Simmons, I. G. 1993. Interpreting Nature: Cultural Constructions of the Environment. London: Routledge.

Singer, Peter. 1975. Animal Liberation: A New Ethics for Our Treatment of Animals. New York: Avon Books.

- 1993. Practical Ethics. Second ed. Cambridge: Cambridge University Press.

Smith, David M. 1998. Geography and Moral Philosophy: Some Common Ground. Ethics, Place and Environment 1 (1):5-34.

Smith, Neil. 1984. Uneven Development: Nature, Capital and the Production of Space. Oxford: Basil Blackwell.

Smith, P. Christopher. 1991. Hermeneutics and Human Finitude: Toward a Theory of Ethical Understanding. New York: Fordham University Press.

Sorabji, Richard. 1993. Animal Minds and Human Morals: The Origins of the Western Debate. Ithaca: Cornell University Press.

Soule, Michael E., and Gary Lease, eds. 1995. Reinventing Nature? Responses to Postmodern Deconstruction. Washington, DC: Island Press.

Spiegel, Marjorie. 1988. The Dreaded Comparison: Human and Animal Slavery. Philadelphia: New Society Publishers.

Symanski, Richard. 1994. Contested Realities: Feral Horses in Outback Australia. Annals of the Association of American Geographers 84 (2):251-269.

1994. Why We Should Fear Postmodernists. Annals of the Association of American Geographers 84 (2):301-304.

Taylor, Paul W. 1986. Respect for Nature: A Theory of Environmental Ethics. Princeton: Princeton University Press. 
William S. Lynn

Toulmin, Stephen. 1986. The Place of Reason In Ethics. Chicago: University of Chicago Press.

Toulmin, Stephen, and Albert R. Jonsen. 1988. The Abuse of Casuistry: A History of Moral Reasoning. Berkeley: University of California Press.

von Wright, Georg Henrik. 1993. The Tree of Knowledge and Other Essays. New York: E. S. Brill.

Warren, Karen J., ed. 1994. Ecological Feminism. New York: Routledge.

Wescoat, James L. 1995. The 'Right of Thirst' for Animals in Islamic Law: A Comparative Approach. Environment and Planning D: Society and Space 13 (6):637-654.

White, Lynn. 1968. The Historical Roots of Our Ecologic Crisis. In Machina Ex Deo: Essays in the Dynamism of Western Culture, edited by L. White. Boston: MIT Press.

Willems-Braun, Bruce. 1997. Buried Epistemologies: The Politics of Nature in (Post)colonial British Columbia. Annals of the Association of American Geographers 1:3-31.

Wilson, Edward O. 1984. Biophilia: The Human Bond With Other Species. Cambridge: Harvard University Press.

Winner, Langdon. 1986. The Whale and the Reactor: A Search for Limits in an Age of High Technology. Chicago: University of Chicago Press.

Wolch, Jennifer, and Jody Emel. 1995. Guest Editorial: Bringing the Animals Back In. Environment and Planning D: Society and Space 13 (6):632-636.

1995. Special Issue: Bringing the Animals Back In. Environment and Planning D: Society and Space 13 (6):631-760. eds. 1998. Animal Geographies: Place, Politics and Identity in the Nature-Culture Borderlands. London: Verso.

Wolch, Jennifer R., Kathleen West, and Thomas E. Gaines. 1995. Transspecies Urban Theory. Environment and Planning D: Society and Space 13 (6):735-760.

Zimmerman, Michael. 1994. Contesting Earth's Future: Radical Ecology and Postmodernity. Berkeley: University of California Press. 